INTERNATIONAL JOURNAL OF MULTidisciplinARY RESEARCH AND ANALYSis

ISSN(print): 2643-9840, ISSN(online): 2643-9875

Volume 04 Issue 02 February 2021

DOI: 10.47191/ijmra/v4-i2-03, Impact Factor: 6.072

Page No.- 125-129

\title{
Body Posture Criteria in Receiving Ball Technique Based on Body Height Indoor Hockey Player
}

\author{
Iskandar Zulkarnaen ${ }^{1}$, Hernawan ${ }^{2}$, Sudradjat Wirahadihardja ${ }^{3}$, Kurnia Tahki ${ }^{4}$, Iwan Sugihartono ${ }^{5}$, \\ Achmad Ainul Yaqin ${ }^{6}$ \\ 1,2,3,4 Physical Education, Universitas Negeri Jakarta, Indonesia \\ 5,6 Mathematics and Natural Science, Universitas Negeri Jakarta, Indonesia
}

ABSTRACT: The purpose of this research is to acknowledge body stance in receiving ball technique. Indoor hockey is a sport with high intensity. Indoor hockey has some basic techniques, one of them is receiving ball technique. Author of this research analyzes the receiving ball technique based on body stance which consists of starting stance, execution stance, and ending stance. The Body stance from receiving ball technique has been demonstrated by Hockey players of Sport Science Faculty of Jakarta State University. Data of this research is collected by observations, interviews, and questionnaire filling requests. This research aims to make tracer study of ideal receiving ball technique based on body height. This research is using qualitative methods by distributing questionnaires to each athlete. Population of this research is Hockey athletes of Jakarta State University, data sample is collected by using total sampling technique. The results of this research is the respondents stated there that playing experience, convenience, and body stance support the receiving ball ability is shown respectively with completely agreed and agreed percentage by $37 \%$ and $41 \%, 44 \%$ and $48 \%, 52 \%$ dan $37 \%$. Furthermore, body height and arm length are respectively shown with disagreed and hesitant percentage by $48 \%, 30 \%$, and $33 \%$, $37 \%$. It means body height and arm length did not affect respondent's accuracy for doing receiving ball. Nevertheless, the hand grips affect accuracy and convenience, this was corroborated by completely agreed and agreed percentage by $70 \%$ and $15 \%$ and hand grip based on convenience is $37 \%$ and $44 \%$. Furthermore, the result of this research will be distributed to athletes and coaches as evaluation material.

KEYWORDS: Hockey Basic Technique, Receiving the Ball, Indoor Hockey, Anthropometry.

\section{INTRODUCTION}

Hockey is a team game played by men or women. Each team tries to score as many goals as possible against the opponent. Hockey is a team sport that brings together 2 teams in a match. Hermawan (Hermawan, 2018), said that hockey is a sport that has the aim of putting as many balls as possible into the opponent's goal and defending the goal itself so as not to concede. A similar statement was also made by Rangasamy (Rangasamy et al., 2020), who said that in hockey, the team that scores more goals is the team that wins the match. Karim (2019), explains that hockey is a sport performed by players who work together to attack, in order to score goals against opponents without forgetting to defend against goals in their own goals. The goal of hockey is to score as many goals as possible and try to keep the goal on your own to avoid conceding the ball. Hockey is a sport which is played by using a bent stick called a stick and a ball. Hockey is a game of skill using tools and sticks (Kailashiya \& Hanjabam, 2014). Latifah (2019) explains that hockey is done using a tool called a stick to play it. Valentino (2018), also argues that hockey is a sport played by two teams where each player uses a stick with a curved tip (stick) and a ball. The side of the stick used to touch the ball is the flat side of the stick or the left side (Brock Symons et al., 2016).

Hockey is a sport of skill that uses a medium called a stick or a ball to play it. The function of using the sticks is to move, dribble, control and hit the ball.

The sport of hockey has three match numbers, namely ice hockey, field hockey and indoor hockey. The three hockey match numbers have different characteristics and ways of playing from one another. Ice hockey uses equipment, such as sticks and balls, which is different from field and indoor hockey. Ice hockey is played on a field covered with solid ice and is elliptical in 


\section{Body Posture Criteria in Receiving Ball Technique Based on Body Height Indoor Hockey Player}

shape, while field and room hockey use almost the same stick and ball, only the weight and thickness distinguish them. Field hockey is a hockey game played on grass or special carpets. The dimensions of the field used are quite large like a soccer game. Field hockey is played by two teams and each team consists of 11 people. Field hockey is usually played by men and women for leisure or recreation or for a competition (Kumar et al., 2015).

Indoor hockey is a sport adapted from field hockey. Indoor hockey is a variation of field hockey (Hollander et al., 2018), but the field used has a smaller scale. The description of indoor hockey is also explained in the rules of indoor hockey, a game played with a board or block on the right and left of the field. The number of players in each team is 12 players. 6 core players and 6 reserve players. The field used in field hockey is $36-44$ in size and 18 - 22 meters wide with a radius of 9 meters and a penalty point of 7 meters. The size of the indoor hockey goal is 3 meters long and 2 meters wide (FIH, 2019).

The basic techniques of hockey include passing, dribbling and receiving. Febrihan (2019), explains that to be able to play hockey well, a player must master some basic techniques such as dribbling, passing the ball, and receiving the ball. Receiving ball is one of the basic hockey techniques that must be mastered. Receiving ball is a technique to stop passing balls from teammates (Hermawan, 2018). According to Katrin in the book field hockey: steps to success "Receiving the hockey ball means fielding the ball on the stick so that it is instantly brought under control without a rebound" (Elizabeth, 1999).

Doing receiving ball technique can be done when the body condition is still or moving. Receiving ball is done to stop the ball going to the area around the player, either from a teammate or from an opponent.

Efforts to do receiving ball technique have two principles that must be done, as expressed by Meng (1996), namely, the player who does it must see the ball until it reaches the stick and the received ball follows the direction of the stopping stick. Receiving ball technique is an effort to lower the sticks down to reach the passing ball from teammates. Receiving ball technique is one of the determining factors in starting the attack. Good receiving ball techniques can put the ball within reach so that the ball can quickly be controlled for control, avoiding opponents, giving to friends, dribbling, or taking shots. Mastery of receiving ball capabilities will make it easier for the players themselves to carry out the desired strategy to help the team win.

Receiving ball technique has two ways, namely re-verse or backhand receiving and forehand receiving. Reverse receiving is done if receiving the ball on the left side of the player collapses while forehand receiving is done if receiving the ball on the right side of the player. Forehand receiving is a technique to stop the ball that is often used, this is because the position of the stick that is used is only the left side. How to do forehand receiving, which is to start holding the stick with the basic grip of the stick, both hands holding the stick with the left hand above and the right hand in the middle of the stick body, the position of the stick is still on the surface of the court, the position of the body bent and footrests shoulder width apart, then lower the stick until it touches the surface of the court, the position of the stick that is low so that it touches the surface of the court can make the ball reception area wider and increase the chances of this technique being successful.

The success of receiving ball technique is influenced by several factors, such as how to hold the grib, body position

Anthropometry, an athlete has a different physical activity according to the sport he is doing. Excessive exercise can interfere with the body's metabolism, hormones, immunity and can have psychological effects, but each athlete's body has a different response. For an athlete, it is important to know his body composition because body composition affects performance in competition and can reduce the risk of injury. The performance of a good athlete will provide a great opportunity for achievement, in addition, body posture and body parts owned by each athlete are one of the factors that influence the appearance of an athlete.

Anthropometric measurements have several variables, including height, weight, BMI, arm length (Sanwaria, M. \& Koley, 2019) (Lemos et al., 2017), these anthropometric measurement variables can be used to identify shapes, sizes, and body topography. Anthropometric measurements are needed to determine the physical condition of an athlete (Maulina, 2018). Anthropometry is useful for knowing the body structure of an athlete and for considering a person's position and training techniques. Basic information about the structure of the human body can be used to estimate the forces acting on the joints and tissues of the body, as well as the resulting forces. The information that has been obtained will be useful in the success of a team.

Height in the world of sports is commonplace and familiar. Height according to Santika is the distance from the vertex to the floor, when the person stands upright, the anatomical body position, and the position of the head in the Frankfort field (Santika \& Subekti, 2020). In line with Santika's statement, Waluyo explained that height is part of anthropometry which describes the state of skeletal growth from the soles of the feet to the tips of the head (Waluyo, 2012). Height under normal conditions, grows as a person gets older. Unlike body weight growth, relative height does not change briefly.

The purpose of this study was to determine the knowledge of Jakarta State University hockey players about the effect of body posture based on height on the success of receiving ball techniques. 


\section{METHOD}

This research uses descriptive qualitative research methods to obtain data through a questionnaire. The purpose of this research is to describe the receiving ball technique for room hockey based on height. This study uses a questionnaire to determine the responses of respondents. The questionnaire was created through the Google Form platform with several indicators such as playing experience, playing knowledge, height, arm length, and distance between handles.

The population in this study were the Hockey athletes at the State University of Jakarta, while the research sample was the entire population sampled (Saturated Sampling).

\section{RESULT AND DISCUSSION}

The data description in this study is a description of the results of the questionnaires that have been filled in by the players.

\section{Playing Experience Indicator}

On the indicator of playing experience, it can be in the view that there were 27 responses came in. There is statement 1 , as many as $48 \%$ answered strongly agree, $41 \%$ answered agree, $7 \%$ answered $b$ disagreed, $4 \%$ answered doubtful, and no one answered strongly disagree. Based on the histogram graph, the highest percentage is $48 \%$ or 13 people who think playing experience greatly affects the success of receiving ball accuracy.

Second statement, $37 \%$ answered strongly agree, $41 \%$ answered agree, $11 \%$ answered doubtful, $7 \%$ answered disagree and $4 \%$ answered strongly disagree. Based on the second statement the highest percentage is $41 \%$ or 11 people agree that playing experience affects the skills in receiving ball technique.

The third, $7 \%$ answered strongly agree, 30\% answered agree, $7 \%$ answered doubtful, $41 \%$ answered disagree and $15 \%$ answered strongly disagree. Based on the third statement, the largest percentage $41 \%$ or 11 people disagree that accurate receiving ball technique is not derived from playing experience.

The fourth, no one answered strongly agree, $15 \%$ answered agree, $33 \%$ answered doubtfully, $41 \%$ answered disagree and $11 \%$ answered strongly disagree. Based on the fourth statement, the largest percentage $41 \%$ or 11 people disagree that playing experience does not determine the accuracy of receiving ball technique.

\section{Play Knowledge Indicator}

Indicator of play knowledge, there were 27 responses entered. In the fifth statement histogram graph, $44 \%$ answered strongly agree, $48 \%$ answered agree, $4 \%$ answered doubtful, $4 \%$ answered disagree and no one answered strongly disagree. Based on the fifth statement, the largest percentage of $48 \%$ or 13 people agree that receiving ball technique is influenced by the comfort of holding the stick.

The sixth, 52\% answered strongly agree, 37\% answered agree, $7 \%$ answered doubtful, $4 \%$ answered disagree and no one answered strongly disagree. The largest percentage of $52 \%$ or 14 people strongly agree that body posture will determine the receiving ball technique.

The seventh, 30\% answered strongly agree, 52\% answered agree, $11 \%$ answered doubtful, $7 \%$ answered disagree and no one answered strongly disagree. The largest percentage $52 \%$ or 14 people agree that players who have more knowledge of hockey will make the receiving ball technique better.

The eighth, $4 \%$ answered strongly agree, 19\% answered agree, 33\% answered doubtful, 33\% answered disagree and $11 \%$ answered strongly disagree. The largest percentage of $33 \%$ or 9 is in doubt choices and $33 \%$ or 9 people disagree that playing knowledge does not affect the accuracy of a player's receiving ball technique.

\section{Height Indicator}

On the indicator of body height, it can be seen that there were 27 responses received. In the statement ninth, $7 \%$ answered strongly agree, $15 \%$ answered agree, $30 \%$ answered doubtful, $48 \%$ answered disagree and no one answered strongly disagree. The largest percentage of $48 \%$ or 13 people disagree that height affects the accuracy of a player's receiving ball technique.

Tenth, $7 \%$ answered strongly agree, $7 \%$ answered agree, $26 \%$ answered doubtful, $56 \%$ answered disagree and $4 \%$ answered strongly disagree. Based on the tenth histogram graph, the largest percentage of $56 \%$ or 15 people disagree that the taller a player is, the better the accuracy of the receiving ball technique.

Eleventh, $7 \%$ answered strongly agree, $7 \%$ answered agree, $26 \%$ answered doubtful, 56\% answered disagree and $4 \%$ answered strongly disagree. Based on the tenth histogram graph, the largest percentage of $56 \%$ or 15 people disagree that the taller a player is, the better the accuracy of the receiving ball technique. 


\section{Arm Length Indicator}

On the arm length indicator, there were 27 responses entered there were $11 \%$ answered strongly agree, $15 \%$ answered agree, $37 \%$ answered doubtfully, $33 \%$ answered disagree and $4 \%$ answered strongly disagree. Based on the twelfth histogram graph, the greatest percentage is $37 \%$ or 10 people doubt that accurate receiving ball technique skills are affected by arm length.

Thirteenth, $7 \%$ answered strongly agree, 15\% answered agree, 37\% answered doubtful, $37 \%$ answered disagree and $4 \%$ answered strongly disagree. The largest percentage $37 \%$ or 10 people disagreed and $37 \%$ or 10 people doubted that the longer a hockey player's arm, the better the receiving ball's accuracy

Fourteenth, 8\% answered strongly agree, 15\% answered agree, 37\% answered doubtful, 33\% answered disagree and $7 \%$ answered strongly disagree. The largest percentage $37 \%$ or 10 people doubt that the length of a player's arm can determine the accuracy of a receiving ball technique.

Fifteenth, 15\% answered strongly agree, $41 \%$ answered agree, $29 \%$ answered doubtful, $11 \%$ answered disagree and $4 \%$ answered strongly disagree. The largest percentage $41 \%$ or 11 people agree that accurate receiving ball technique is not derived from the length of a player's arm.

\section{Distance between Handles Indicator}

On the distance between handles indicator, there were 27 responses were received. On the histogram graph of the sixteenth statement, $15 \%$ answered strongly agree, $70 \%$ answered agree, $8 \%$ answered doubtful, $7 \%$ answered disagree and no one answered strongly disagree. The largest percentage $70 \%$ or 19 people agree that accurate receiving ball technique is affected by the distance between the handrails.

Seventeenth, $7 \%$ answered strongly agree, 30\% answered agree, $41 \%$ answered doubtful, $22 \%$ answered disagree and no one answered strongly disagree, the largest percentage $41 \%$ or 11 people doubted that the farther the distance between the handles hand, the better receiving player's accuracy.

Eighteenth, 37\% answered strongly agree, 52\% answered agree, $7 \%$ answered doubtful, $4 \%$ answered disagree and no one answered strongly disagree. The largest percentage $52 \%$ or 14 people agree that the distance between the hands determines the accuracy of a player's receiving ball technique.

Nineteenth, 37\% answered strongly agree, 44\% answered agree, 15\% answered doubtfully, no one answered disagree and $4 \%$ answered strongly disagree. The largest percentage $44 \%$ or 12 people felt that the distance between the handles based on comfort affects accurate receiving ball technique

\section{CONCLUSIONS}

Based on the results of the analysis and discussion, it can be concluded that the playing experience, comfort, body posture of the respondent supports the receiving ball's ability, which respectively indicated by the percentages of strongly agreeing and agreeing are $37 \%$ and $41 \%, 44 \%$ and $48 \%, 52 \%$. And $37 \%$.

Furthermore, for height, the largest percentage was $48 \%$ disagree and $30 \%$ doubtful, for arm length the largest percentage was $37 \%$ doubtful and $33 \%$ disagreed. This means that height and arm length do not affect the accuracy of respondents on receiving ball.

However, the distance between the handrails affects the accuracy and comfort, this is reinforced by the percentage strongly agree and agree that the distance between the handrails affects the accuracy is $70 \%$ and $15 \%$ and the distance between the handles based on comfort is $37 \%$ and $44 \%$.

\section{REFERENCES}

1) Aikman et al. (2019). Analisis ketepatan hasil pukulan normal grip dan short grip dalam permainan hockey untuk pemula. Keolahragaan, 5(April 2020), 37.

2) Brock Symons, T., Roberts, A. H., Walden, A. J., \& Carter, K. A. (2016). Influence of High-Intensity Training on Power Production in High School Field Hockey Players. Medicine \& Science in Sports \& Exercise, 48, 865.

https://doi.org/10.1249/01.mss.0000487592.51922.75

3) Effendi, A. R. 2015. (2015). Hubungan Latihan Kekuatan Otot Lengan Dan Panjang Lengan Terhadap Kemampuan Service Atas Permainan Bola Voli. Jurnal Pendidikan Olahraga, 4(1), 44-55.

4) Elizabeth, A. (1999). 2rd Steps to success sports series Elizabeth Anders_Sue Myers - Field hockey.

5) Febrihan, A. S. (2019). KONTRIBUSI KELINCAHAN DAN KEKUATAN OTOT LENGAN TERHADAP KETERAMPILAN INDIAN DRIBBLE PADA SISWA EKSTRAKURIKULER HOCKEY DI SMA NEGERI 1 MENGANTI Ainus. Jurnal Kesehatan Olahraga, 7(2), 367-372. https://doi.org/10.1017/CBO9781107415324.004 
6) FIH. (2019). Rules Of Indoor Hockey. The International Hockey Federation, October 2019, 67. http://fih.ch/media/12236439/fih-rules-of-indoor-hockey-2019.pdf

7) Hermawan, I. (2018). Pengaruh Model Peer Teaching terhadap Motivasi dalam Pembelajaran Hockey. Khazanah Akademia Vol. 02; No. 01; 2018; 1-9, 02(01), 1-9.

8) Hollander, K., Wellmann, K., Eulenburg, C. Z., Braumann, K. M., Junge, A., \& Zech, A. (2018). Epidemiology of injuries in outdoor and indoor hockey players over one season: A prospective cohort study. British Journal of Sports Medicine, 52(17), 1091-1096. https://doi.org/10.1136/bjsports-2017-098948

9) Kailashiya, J., \& Hanjabam, B. (2014). Study of Ball Hitting Speed and Related Physiological and Anthropometric Characteristics in Field Hockey Players. Asian Academic Research Journal of Multidisciplinary, August, 398-410. www.asianacademicresearch.orgwww.asianacademicresearch.org

10) Latifah, N. N., Margawati, A., \& Rahadiyanti, A. (2019). Hubungan komposisi tubuh dengan kesegaran jasmani pada atlet hockey. Jurnal Keolahragaan, 7(2), 146-154. https://doi.org/10.21831/jk.v7i2.28085

11) Lemos, R. S., Paz, G. A., De Freitas Maia, M., Da Silva, J. B., Lima, V. P., De Castro, J. B. P., \& Miranda, H. (2017). Anthropometric and Physical fitness parameters versus specific performance tests in Brazilian field hockey athletes: $A$ pilot study. Biomedical Human Kinetics, 9(1), 57-63. https://doi.org/10.1515/bhk-2017-0009

12) Maulana Misfajar, S. (2019). Analisis Antropometri Dan Kondisi Fisik Pemain Bolabasket Putra. Indonesia Performance Journa, 2(1), 8-12.

13) Maulina, M. (2018). Profil Antropometri Dan Somatotipe Pada Atlet Bulutangkis. AVERROUS: Jurnal Kedokteran Dan Kesehatan Malikussaleh, 1(2), 69. https://doi.org/10.29103/averrous.v1i2.413

14) Meng, Y., Dahaban, A., Singh, P., \& Leong, T. (1996). HOKI.

15) Milić, M., Grgantov, Z., Chamari, K., Ardigò, L. P., Bianco, A., \& Padulo, J. (2017). Anthropometric and physical characteristics allow differentiation of young female volleyball players according to playing position and level of expertise. Biology of Sport, 34(1), 19-26. https://doi.org/10.5114/biolsport.2017.63382

16) Rangasamy, K., As'ari, M. A., Rahmad, N. A., \& Ghazali, N. F. (2020). Hockey activity recognition using pre-trained deep learning model. ICT Express, 6(3), 170-174. https://doi.org/10.1016/j.icte.2020.04.013

17) Sanwaria, M. \& Koley, S. (2019). A Study of Anthropometric Variables, Back strength and Performance Tests in International Journal of Health Sciences and Research A Study of Anthropometric Variables, Back strength and Performance Tests in Inter- University Hockey Players. 9(September), 20-27.

18) Saraya, A. E. (2018). Anthropometric Factors and Physical Condition Dominant Determinants Batting Skills In Softball. Jurnal Pendidikan Jasmani Dan Olahraga, 3(1), 74. https://doi.org/10.17509/jpjo.v3i1.10331

19) Sharma, A., Tripathi, V., \& Koley, S. (2012). Correlations of anthropometric characteristics with physical fitness tests in Indian professional hockey players. Journal of Human Sport and Exercise, 7(3), 698-705.

https://doi.org/10.4100/jhse.2012.73.09

20) Subakti, S. (2013). Hubungan Kecepatan, Kelincahan dan Kekuatan Otot Tungkai terhadap Kemampuan Mengkontrol Bola dalam Permainan Hockey Atlet Putri Pelatda Sumatera Utara Persiapan PON XVII Kalimantan Timur. IImu Keolahragaan, 12(1), 52-59.

21) Valentino, R. F., \& Akbar, I. H. (2018). PENGARUH LATIHAN MENGGUNAKAN MEDIA AUDIO VISUAL TERHADAP KETERAMPILAN TEKNIK PUSH PADA CABANG OLAHRAGA HOKI. Jurnal Kepelatihan Olahraga, 10(1), 13-25.

22) Vinson, D., \& Peters, D. M. (2015). Position-specific performance indicators that discriminate between successful and unsuccessful teams in elite women's indoor field hockey: implications for coaching. Journal of Sports Sciences, 34(4), 311-320.

23) Waluyo, R. M. (2012). Hubungan Berat Badan Tinggi Badan Dan Panjang Tungkai Dengan Kelincahan. Journal of Sport Sciences and Fitness, 1(2), 26-31. 